\title{
ESTRATIGRAFIA E SEDIMENTAÇÃO DA BACIA SANFRANCISCANA: UMA REVISÃO
}

\author{
JOSÉ ELOI GUIMARÃES CAMPOS \& MARCEL AUGUSTE DARDENNE
}

\begin{abstract}
STRATIGRAPHY AND SEDIMENTATION OF THE SANFRANCISCANA BASIN: A REVIEW This paper presents a stratigraphic and depositional systems review to the Phanerozoic cover of the São Francisco Craton, defined as the Sanfranciscana Basin.

The Phanerozoic cover is composed mainly of sedimentary continental rocks and minor explosive volcanic rocks. The stratigraphy and sedimentology of the Phanerozoic successions are summarized as follows:

Santa Fé Group (Carboniferous-Permian) -divided into Floresta and Tabuleiro formations. This glaciogenic sequence represents the gondwanan glaciation record in the Sanfranciscana Basin. These sediments are preserved in valleys excavated in the basement and crop out in most of the basin

Areado Group (Early Cretaceous) -constituted by the Abaeté, Quiricó and Três Barras formations, characterized by lateral and vertical interfingerings. The Abaeté Formation was deposited by braided stream and the in southern area by alluvial fans; the Quiricó Formation records a lacustrine sedimentation. and the Três Barras Formation, was deposited in the fluvial, fluviodeltaic and aeolian environments. The Areado Group is thick in southern portion of the basin (200 meters); it is less than 60 meters and discontinous in the central-northern areas.

Mata da Corda Group (Late Cretaceous) -composed by the Patos and Capacete formations. The Patos Formation is composed by alkaline volcanic rocks. The Capacete Formation represents the distai epiclastic sediments with important aeolian sand contribution. It is present only in the southern sector of the basin.

Urucuia Group (Late Cretaceous) - composed of sandstones, divided into Posse (with Facies 1 e 2) and Serra das Araras formations, respectively interpreted as dry field dune deposits, braided stream of channelized deposition and braided stream deposited by sheet flows. It is present in the entire basin. In the southern portion of the basin, it is recovered by volcaniclastic sediments, and in the northern area it becomes the most important unit.

Chapadão Formation (Quaternary), represents the recent sandy, unconsolidated, covers of talus, residual or alluvium origin.

Provenance studies show the following transportation vectors and source areas: Santa Fé Group - NE to S W transport, with source areas in Northern Espinhaço Range and in the Bambuí Group; Areado Group - transport from the adjacent elevated blocks, showing important axial flow; Urucuia Group - transport from NEE to SWW, with sources in the northest São Francisco Craton and the Capacete Formation - showing two directions of transport: volcanic rocks from South to North and aeolian sand from NE to SW.
\end{abstract}

Key-words: Phanerozoic cover, Sanfranciscana Basin, Stratigraphy, Sedimentation.

RESUMO Este trabalho apresenta a revisão da estratigrafia e dos sistemas deposicionais da Cobertura Fanerozóica do Craton do São Francisco - Bacia Sanfranciscana.

A cobertura sedimentar é constituída essencialmente por rochas depositadas em ambientes continentais e rochas vulcâniças piroclásticas subordinadas, apenas presentes na porção sul da bacia. A estratigrafia das sucessões fanerozóicas inclui as seguintes unidades:

Grupo Santa Fé (Permo-Carbonífero) é sub-dividido nas formações Floresta e Tabuleiro. Este conjunto de origem glaciogênica representa os registros da glaciação gonduânica neopaleozóica na Bacia Sanfranciscana. Estes sedimentos ocorrem preservados em vales escavados no embasamento, com afloramentos descontínuos por toda a extensão da bacia.

Grupo Areado (Eocretáceo) é constituído pelas formações interdigitadas Abaeté (basal), Quiricó e Três Barras. A Formação Abaeté foi depositada por leques aluviais na porção sul da bacia e por sistemas fluviais entrelaçados nas demais regiões da bacia; a Formacão Quiricó mostra uma sedimentacão lacustre, localmente caracterizada por lagos estratificados, e a Formação Três Barras, depositada em ambientes fluviais, fluviodeltáicos e eólicos. Esta unidade apresenta maior espessura na porção sul da bacia ( 200 metros), enquanto, na região centro-norte, suas ocorrências são mais descontínuas e delgadas (máximo 60 metros).

Grupo Mata da Corda (Neocretáceo) é composto pelas formações Patos e Capacete. A Formação Patos é composta por rochas vulcânicas alcalinas. A Formacão Capacete é representada por sedimentos epiclásticos distais sedimentados a partir de fontes vulcânicas, com importante contribuição de areias eólicas. Ocorre apenas na porção sul da área estudada.

Grupo Urucuia (Neocretáceo) é composto por arenitos, tendo sido sub-dividido nas formações Posse (com as Fácies 1 e 2 ) e Serra das Araras, respectivamente interpretadas como depósitos eólicos de campos de dunas secas, fluvial entrelaçado depositado em canais e fluvial entrelacado sedimentado em lencóis de areia e cascalho. Está presente desde o sul da bacia, onde é preservado em áreas isoladas e recoberto por sedimentos epiclásticos, até o norte da bacia, onde se torna a unidade predominante.

Formação Chapadão (Cenozóico), representa as coberturas arenosas, inconsolidadas, recentes, de caráter eluviocoluvionar ou aluvionar.

Estudos de proveniência para as várias unidades indicaram os seguintes vetores de transporte e áreas fontes: Grupo Santa Fé - transporte de NE para SW com áreas fontes representadas pela Serra do Espinhaço Setentrional e pelo Grupo Bambuí; Grupo Areado - transporte a partir dos blocos elevados adjacentes à bacia e importante fluxo axial de SW para NE, tendo os sedimentos do Grupo Santa Fé representado material fonte para a Formação Abaeté; Grupo Urucuia - transporte de NEE para SWW, com fontes situadas na porcão NE do Craton do São Francisco e Formação Capacete - apresenta dupla direcão de transporte, com contribuição de rochas vulcânicas de sul para norte e contribuição de areias eólicas de NE para SW.

Palavras-chave: Cobertura fanerozóica, Bacia Sanfranciscana, Estratigrafia, Sedimentação.

INTRODUÇÃO O principal objetivo deste trabalho é sintetizar o conhecimento da cobertura sedimentar fanerozóica do Craton de São Francisco na região conhecida como Bacia Sanfranciscana, procurando apresentar novos dados relativos à lito-estratigrafia, sistemas deposicionais e paleogeografia desta bacia.
As denominações Bacia Sanfranciscana (Sgarbi, 1989), Bacia do São Francisco (Sad et al, 1971) ou Bacia Alto Sanfranciscana (Hasui \& Haralyi, 1991) têm sido, ao longo do tempo, utilizadas para designar a depressão na qual se acumularam as coberturas fanerozóicas sobre o Craton do São Francisco. O termo Bacia do São Francisco não é indicado 
como referência à cobertura fanerozóica do cráton, pois frequentemente traz confusões com a denominação "Bacia do São Francisco" referente aos sedimentos proterozóicos do Supergrupo São Francisco. Comumente esta terminologia ambígua causa problemas de comunicação entre os vários pesquisadores que trabalham no Cráton do São Francisco. Por outro lado, a denominação de Bacia Alto Sanfranciscana não é satisfatória, pois a bacia não se limita arealmente a porção da bacia hidrográfica que define o alto Rio São Francisco. A bacia se estende para norte, alcançando regiões do médio Rio São Francisco e incluindo áreas do extremo sul do Estado do Piauí, ocupando uma área total de cerca de $150.000 \mathrm{~km}^{2}$. O termo mais apropriado para o conjunto dos sedimentos fanerozóicos do cráton é consequentemente Bacia Sanfranciscana.

Importantes diferenças tectônicas, estratigráficas e ambientais entre a porção sul e a porção norte permitem a divisão em duas sub-bacias aqui informalmente denominadas SubBacia Abaeté e Sub-Bacia Urucuia, separadas por um alto estrutural do embasamento denominado de Alto do Paracatu.

\section{O EMBASAMENTO DA BACIA SANFRANCISCANA}

Como embasamento da Bacia Sanfranciscana são consideradas todas as unidades que funcionaram como substrato para a deposição das sucessões fanerozóicas.

$\mathrm{O}$ embasamento da porção central da bacia é representado pelo Grupo Bambuí. No extremo sul (região de Lagoa Formosa/MG), ocorrem metassedimentos de baixo grau com metadiamictitos associados, correlacionáveis ao Grupo Bambuí. Faixas de rochas xistosas, graníticas ou gnáissicas arqueanas/ proterozóicas afloram no meio norte da bacia nas regiões de Coribe-Correntina/BA, São Domingos/GO e Dianópolis/TO, sendo atribuídas ao embasamento granitognáissico. Na porção setentrional, a norte do paralelo $12^{\circ} 30^{\prime}$, os sedimentos da Bacia Sanfranciscana recobrem a seção paleozóica da Bacia do Parnaíba.

De forma geral, os sedimentos fanerozóicos recobrem regiões cratônicas, pouco perturbadas tectonicamente, sendo o Grupo Bambuí disposto horizontalmente ou suavemente ondulado. Apenas na porção oeste da Sub-Bacia Abaeté aparecem metassedimentos intensamente dobrados do Grupo Bambuí e importantes falhas regionais.

AS COBERTURAS FANEROZÓICAS As associações faciológicas, atualmente formalizadas para a Bacia Sanfranciscana, foram definidas a partir de estudos de geologia de superfície. A estratigrafia inclui unidades neopaleozóicas, eocretáceas e neocretáceas. Apesar das rochas mais antigas serem atribuídas ao Permo-Carbonífero, não se descarta a possibilidade da existência de sucessões mais antigas que, caso existam, são subaflorantes, devendo ser encontradas nos depocentros da Sub-Bacia Urucuia.

Geralmente as unidades mesozóicas que constituem o maior registro sedimentar da Sub-Bacia Abaeté, são tratadas como formação (formações Areado, Mata da Corda e Urucuia). O presente trabalho propõe que tais unidades sejam elevadas ao status de Grupo, como já havia sido proposto por alguns trabalhos prévios (e.g. Barbosa 1965) e utilizado por alguns autores em trabalhos mais recentes (e.g. Kattah 1994).

Dessa forma, os membros pertencentes a cada uma destas unidades passam a formações, ou seja, Grupo Areado com as formações Abaeté, Quiricó e Três Barras, Grupo Mata da Corda com as formações Patos e Capacete e Grupo Urucuia com as formações Posse e Serra das Araras.

A figura 2 ilustra a carta estratigráfica integrada apresentada para a Bacia Sanfranciscana, na qual podem-se notar as diferenças observadas entre os segmentos sul e centro-norte.

É importante salientar que a divisão litoestratigráfíca proposta está perfeitamente de acordo com as normas do código brasileiro de nomenclatura estratigráfica atualmente em vigor (Petriefa et al. 1986a e 1986b).

GRUPO SANTA FÉ -NEOPALEOZÓICO O Grupo Santa Fé é a unidade fanerozóica mais antiga conhecida na bacia. É representado por um conjunto de sedimentos de origem glaciogênica que é correlacionável a unidades neopaleozóicas da Bacia do Paraná (grupos Aquidauana e Itararé). Esta unidade estratigráfica foi definida a partir dos trabalhos de Dardenne et al (1991), Campos (1992) e Campos \& Dardenne (1994).

O contato basal do Grupo Santa Fé com o embasamento caracteriza a primeira discordância regional da Bacia Sanfranciscana.

Os registros atuais do Grupo Santa Fé, caracterizados por escassas áreas de afloramento são localmente preservados em paleo-depressões do embasamento que representam prováveis paleo-vales glaciais. Embora apresente pequeno volume e extensões restritas de afloramentos, esta unidade possui registros em toda a área estudada, tendo sido cartografada ou observada desde o Vale do Rio São Francisco na porção sul, até a região de Posse/GO na porção norte da bacia.

Este grupo é composto pelas formações Floresta e Tabuleiro. A Formação Floresta é dividida em três membros lateralmente interdigitados: Brocotó, Brejo do Arroz e Lavado. A Formação Tabuleiro recobre os membros da Formação Floresta além de ocorrer diretamente sobre o Grupo Bambuí.

As áreas-tipo (Campos 1992) estão situadas em Canabrava e Santa Fé de Minas/MG. Sua espessura máxima alcança 180 metros na região de Santa Fé de Minas. A norte do Rio Urucuia, o Membro Brejo do Arroz atinge 70 metros de espessura. No geral, os sedimentos do Grupo Santa Fé somam 60 a 80 metros de espessura na maioria dos sítios de ocorrência.

Caracterização Litofaciológica e Sedimentação do Grupo Santa Fé As feições das litofácies glaciogênicas como: o predomínio de arenitos, o pequeno volume de diamictitos, as rápidas mudanças laterais, a grande distância dos supostos centros glaciais e as constantes feições de ressedimentação, mostram que se trata de uma glaciação em condições temperadas (Eyles et al. 1983). Este tipo glaciação implica em temperaturas elevadas com médias anuais em torno de $3^{\circ} \mathrm{C}$, alta velocidade de fluxo de geleiras (10 a 200 metros por ano) e pequena espessura de fácies de diamictitos basais (100 metros).

Os sedimentos do Grupo Santa Fé apresentam uma série de registros que comprovam a existência da glaciação neopaleozóica na Bacia Sanfranciscana, como a presença de pavimentos estriados com fraturas em crescente, observados na região de Santa Fé de Minas/MG (Dardenne et al. 1991), materiais caídos em fácies de folhelhos, às vezes estriados, com variadas formas, tamanho e composição, muito comuns nas regiões de Canabrava e Santa Fé de Minas, associações típicas de litofácies proglaciais (fluvio-glacial, glacio-lacustre e eólico periglacial), conforme Ashley et al. (1985), presença de seixos estriados em diamictitos e natureza síltico-argilosacalcífera da matriz, ocorrência dos sedimentos em largos vales em $\mathbf{U}$ separados por altos do embasamento.

FORMAÇÃO FLORESTA Apresenta três subunidades interdigitadas, tendo sido caracterizadas com membros e dessa forma, incluídas em apenas uma formação.

Membro Brocotó O Membro Brocotó é constituído essencialmente por diamictitos de coloração vermelho tijolo. Estes diamictitos são geralmente desorganizados e apresentam variações nas proporções de matriz (de 30 a 80\%). 


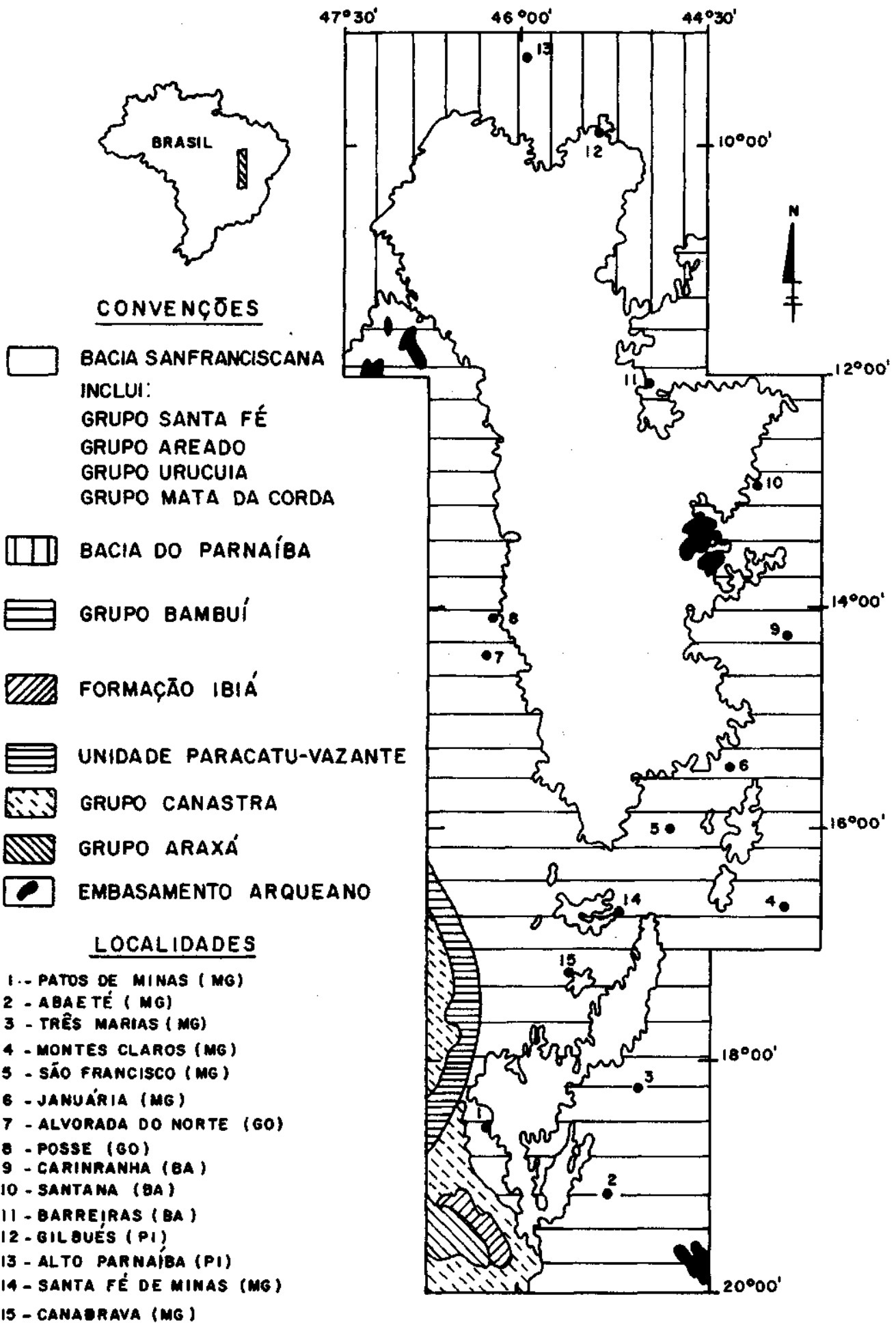

Figura l - Situação regional da Bacia Sanfranciscana e distribuição de seu embasamento Figura 1 - Regional situation of the Sanfranciscana basin and distribution of the main basement

O grau de organização (selecionamento, acamamento, arredondamento, etc) é o parâmetro mais importante para classificá-los nas fácies de tilitos ou tilóides. Os tilitos verdadeiros são raros e caracterizados pelos tipos maciços ou pouco estratificados, com clastos angulosos e estriados. Incluem os tipos Dmm, Dmm(s) e Dm(s) da classificação de Eyles et al. (1983). As fácies de tilóides incluem os diamictitos estratifi- cados com seixos e calhaus mais arredondados, e comumente menores quantidades de matriz, caracterizando os tipos Dmm(r), Dmm(c), Dms(r) e Dms(c) de Eyles et al. (1983).

Os clastos apresentam diâmetros que variam de centímetros a metros, mas na maioria dos casos são decimétricos (de 10 a 40cm). São encontrados clastos com formas desde angulosas a subarredondadas, comumente com uma base 


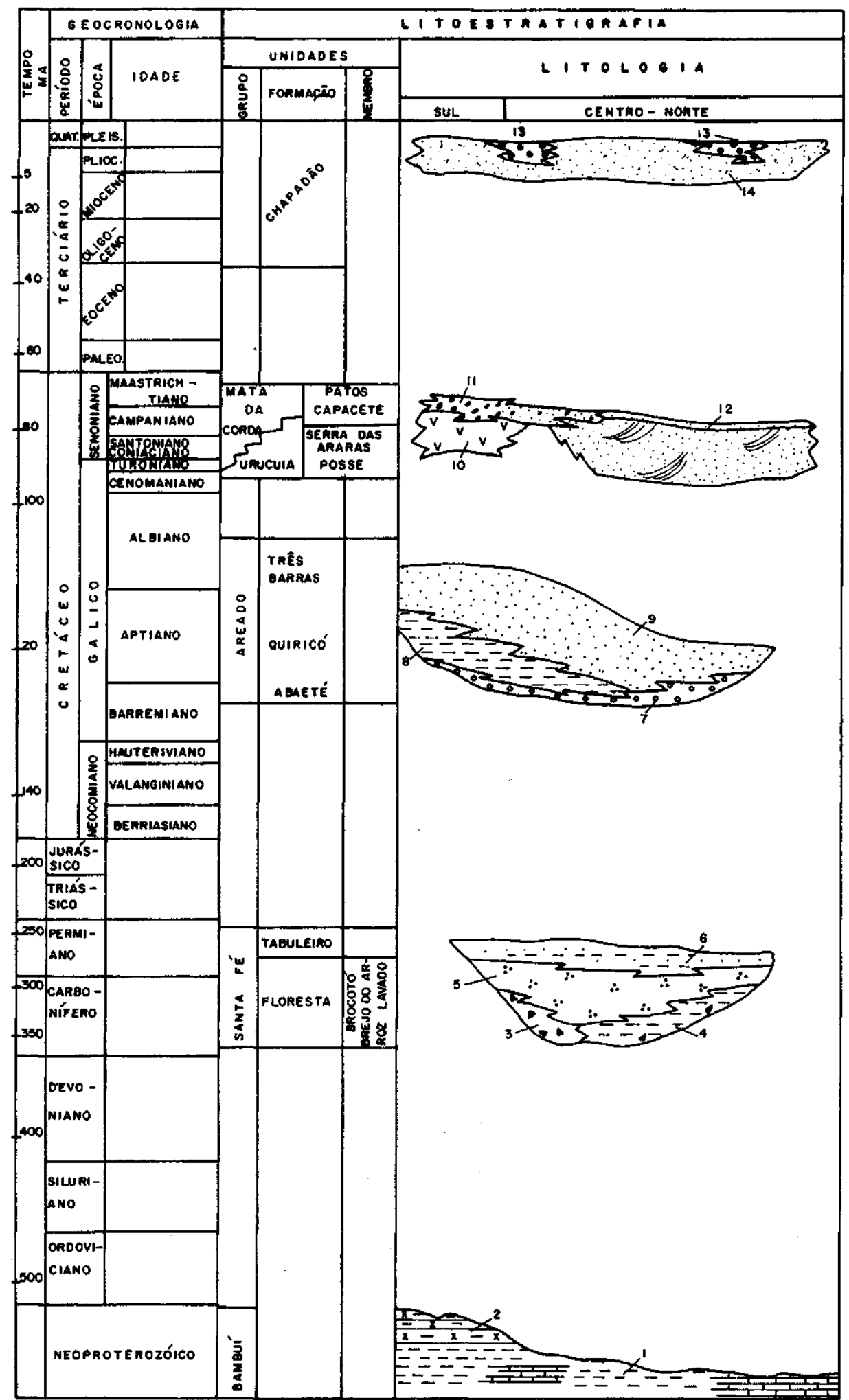

Figura 2 - Estratigrafia da Bacia Sanfranciscana. Principais litotipos: 1 - sequência pelito carbonática, 2 - arcóseos e siltitos, 3 - diamictitos, tilitos e tilóides, 4 - folhelhos com dropstones, 5 - arenitos heterogêneos, 6 - arenitos maciços calcíferos com intercalações argilosas, 7 - conglomerados e arenitos, 8 -folhelhos, 9 - arenitos, 10 - lavas e piroclásticas alcalinas, 11 - arenitos vulcânicos, 12 - arenitos eólicos, 13 - conglomerados de terraços e 14 - areias inconsolidadas.

Figure 2 - Stratigraphy of the Sanfranciscana Basin. Main rock types: 1 - pellitic carbonated sequency, 2 - arkoses and siltstones, 3 - diamictites and tillites, 4 shales bearing mudstone, 5 - heterogenous sandstones, 6 - massive calcitic sandstones with pellitic intercalations, 7 - conglomerates and sandstones, 8 - shales, 9

- sandstones, 10 - alcaline lavas and piroclastic rocks, 11 - volcanic sandstones, 12 - aeolian sandstones, 13 - alluvium conglomerates and 14 - unconsolidated sands. 
plana, sendo frequentemente facetados e mais raramente estriados. A composição dos calhaus é principalmente controlada pela natureza do embasamento local, com contribuição subordinada de quartzitos, quartzo e granitos. Assim, os diamictitos encontrados na porção sul da área são constituídos predominantemente por fragmentos de arcóseos da Formação Três Marias, enquanto nos ruditos da região de Posse predominam os clastos de calcários e siltitos. Em raros afloramentos, foram encontrados calhaus de calcita espática.

A matriz de coloração vermelha mostra granulometria variável, desde argilosa a arenosa, sendo mais comumente argilo-síltica-carbonática. Representa uma farinha de rochas, resultante da moagem pela abrasão nas bases das geleiras, sendo o carbonato originado a partir dos calcários do Grupo Bambuí.

Os diamictitos ocorrem em áreas restritas diretamente sobre o embasamento, sendo interdigitados com os demais membros.

Os mecanismos de deposição deste membro são diretamente relacionados à presença de capas de gelo. Podem estar associados a materiais residuais de bases de geleiras em movimento (lodgement till) ou serem produtos de derretimento de capas de gelo saturadas de detritos (melt-out till). Como a região em estudo é caracterizada por paleoclima temperado, os sedimentos do tipo melt-out till são mais comuns.

Além dos tipos de diamictitos associados aos processos descritos anteriormente, ocorrem também grandes volumes de diamictitos originados pelo retrabalhamento de tilitos de acumulação e derretimento. Estes diamictitos caracterizam as fácies de tilóides, sendo sua gênese ligada à ressedimentação por correntes originárias do derretimento de geleiras em períodos de retração das capas de gelo. Este retrabalhamento geralmente se processa através de fluxos a curtas distâncias e, por vezes, envolve transporte a distâncias relativamente grandes como pode ser deduzido pelas fácies ricas em clastos sub arredondados.

Membro Brejo do Arroz É caracterizado por folhelhos vermelhos, rosados ou ocres bem laminados, apresentando clastos caídos. Os clastos caídos: seixos e calhaus (dropstones) ocorrem em proporções variáveis, apresentando desde grandes quantidades (e.g. regiões de Canabrava e Santa Fé de Minas/MG) até pequenas proporções, sendo ausentes em outras regiões (e.g. região de Urucuia/MG).

Associados aos folhelhos, comumente ocorrem intercalações milimétricas a centimétricas de siltitos e arenitos finos. Localmente se destacam níveis contínuos ou lenticulares (decimétricos a métricos) de oito- e paraconglomerados. Pacotes de varvitos, embora não muito comuns, também são observados em diversas posições estratigráficas.

Numerosas estruturas sedimentares são preservadas nos sedimentos deste membro, incluindo marcas onduladas simétricas e assimétricas, laminações cruzadas, estratificações plano-paralelas e climbing ripples nas intercalações arenosas. Mais raramente, são observados ainda canais erosivos e estruturas de carga como dobras convolutas e deslizamentos que ocorrem em escalas variáveis.

Microscopicamente, as intercalações arenosas apresentam imaturidade textural e mineralógica, com feldspatos e ocasionalmente fragmentos líticos intraformacionais. Podem conter matriz detrítica argilosa ou, quando puras, apresentam cimento de calcita cristalina. $O$ estudo das seções delgadas indica a presença de acamamento gradacional e carpetes de tração nas frações de areia média.

Os dropstones encontrados nos folhelhos apresentam formas irregulares, sendo angulosos ou subarredondados, sempre exibindo uma face achatada. Clastos estriados não são raros. Muitas vezes, várias direções de estrias são vistas em um mesmo seixo. São extremamente mal selecionados, com diâmetros variando de milímetros a decímetros e ocasionalmente alcançando metros.

Os fragmentos são caracterizados por uma grande variabilidade de composição, apresentando diversos tipos litológicos: arcóseos, quartzitos, metaconglomerados, metassiltitos, calcários, granitóides variados, gnaisses, milonitos, xistos, filitos, quartzo de veio e itabiritos. De maneira geral os arcóseos da Formação Três Marias são os tipos mais comuns, seguidos pelas rochas mais resistentes como os quartzitos, metaconglomerados e itabiritos. Filitos, xistos e calcários são mais raros.

Associadas aos folhelhos do Membro Brejo do Arroz, ocorrem concreções carbonáticas lenticulares e delgadas camadas $(0,5$ a $3,0 \mathrm{~cm})$ de calcita fibrosa.

Esta unidade representa a sedimentação lacustre diretamente alimentada pelo degelo glacial. A natureza dos sedimentos, com uma grande distribuição lateral, permite concluir que se tratava de lagos termalmente estratificados, possivelmente com um epilímio bem desenvolvido.

Três processos principais foram responsáveis pelo preenchimento dos lagos: deposição por suspensão, por queda de materiais e por fluxos gravitacionais.

O maior volume de sedimentos foi depositado pela agradação vertical de materiais finos, principalmente arguas, que representam as plumas de degelo ingressando nos lagos.

Depósitos por queda de materiais marcam importante feição diagnostica das fácies glacio-lacustres. Os dropstones (seixos, calhaus e matacões caídos), contidos nestes depósitos, representam os detritos soltos por massas de gelo, em derretimento, que flutuavam nos lagos. Estes sedimentos são caracterizados por seixos ou calhaus imersos em folhelhos bem laminados. Para a caracterização desta fácies e distinção das fácies por fluxo de massa é necessária a observação de deformação dos pelitos na base e no topo dos materiais caídos. Sedimentos por fluxo de detritos são definidos pela presença de seixos e calhaus flutuantes em argilitos maciços, denunciando deposição simultânea das frações fina e grossa.

Depósitos por fluxos gravitacionais são gerados a partir da chegada de geleiras saturadas de sedimentos e de seus produtos de derretimento. Este fato muda o contexto deposicional e propicia a geração de correntes de densidade. Dois processos são considerados para a produção das correntes de turbidez: origem a partir dos deltas fluvio-glaciais e a partir do outwash em bases de geleiras terminais.

A desembocadura do sistema fluvio-glacial nos lagos, principalmente em épocas de pronunciado degelo, resulta na geração de canyons que espalham detritos em forma de leques coalescentes em profundidade. Este processo origina principalmente os sedimentos mais finos (arenitos finos, siltitos e argilitos maciços), sendo depositados por correntes de baixa densidade. Na deposição das fácies ricas em climbing ripples e marcas onduladas, aluaram correntes de fundo responsáveis pelo bom selecionamento e estruturas de tração (marcas onduladas, laminações cruzadas truncadas e carpetes de tração). Os materiais pelíticos, que recobrem amplamente os sedimentos mais grossos, correspondem aos estágios finais das correntes de turbidez, representando depósitos distais através de mecanismos de suspensão.

Mutti (1992) propõe um novo modelo para classificação e interpretação de fácies depositadas por processos gravitacionais envolvendo fluxos turbulentos. As "novas fácies turbidíticas" diferem significativamente das fácies de Bouma (1962) por valorizar os processos deposicionais em detrimento às interpretações com bases puramente descritivas. $\mathrm{O}$ modelo de Mutti (1992) considera que fácies muito similares ou com sutis diferenças, podem ser sedimentadas por processos (tipo de fluxo, tipo de transformação da corrente ou mecanismos de suporte) bastante distintos. 
A sedimentação lacustre foi controlada por dois tipos de lagos alimentados por degelo, os lagos proximais e os lagos distais. Sua distinção pode ser feita com base na abundância de sedimentos grossos. Como exemplo, pode-se considerar as regiões de Canabrava e Santa Fé de Minas, onde são comuns turbiditos densos e dropstones, representando paleolagos proximais, enquanto a região de Urucuia, onde são muito raros os materiais caídos e predominam os turbiditos de baixa densidade, a sedimentação é característica dos lagos distais.

Deformações penecontemporâneas, observadas nos folhelhos, resultam em diferentes tipos de dobras desarmônicas, são interpretadas como resultado do escape de fluidos. Este tipo de estrutura se forma pelo peso da pilha sedimentar sobreposta ou por escorregamentos (slumpings) em condições de fundo inclinado (Elliot 1965 e Lowe 1975).

Membro Lavado É constituído por arenitos heterogéneos vermelhos e secundariamente por diamictitos de matriz arenosa, conglomerados e conglomerados intraformacionais. Os arenitos são finos, médios ou grossos, argilosos ou puros, sempre cimentados por calcita, sendo localmente o cimento do tipo sintaxial. Os diamictitos e conglomerados indicam retrabalhamentos, pois são principalmente compostos por fragmentos arredondados dos próprios arenitos.

As estruturas sedimentares são comuns, incluindo laminações cruzadas, estratificações cruzadas acanaladas, feições erosivas de corte e preenchimento, concreções carbonáticas e dobras penecontemporâneas tipo convolutas sendo características desta unidade.

Segundo os critérios de Folk (1956) e Dott (1964) os arenitos são classificados como arenitos feldspáticos calcíferos (as fácies mais comuns), quartzo arenitos, arcóseos, wackes feldspáticos e quartzo wackes (fácies subordinadas).

As feições diagenéticas mais importantes são representadas por uma película de óxidos na borda dos grãos detríticos e pela cimentação por calcita, que oblitera totalmente a porosidade primária (em alguns casos elevada). A coloração vermelha dos arenitos é consequência da presença da película de óxido, vinculada a processos eodiagenéticos de diminuição da porosidade primária.

O Membro Lavado é interdigitado com os membros Brocotó e Brejo do Arroz e representa o maior volume de rochas dentro da Formação Floresta.

Esta unidade representa as fácies fluvio-glaciais marcadas por depósitos de rios entrelaçados alimentados pelo degelo. Este sistema fluvial apresenta fluxo e carga de sedimentos variáveis em resposta aos condicionantes glaciais (retração, avanço, degelo, movimentação de massas glaciais, ruptura de lagos formados pelo barramento por geleiras etc).

A grande distribuição areal desta fácies indica um sistema fluvial com inúmeros canais rasos, instáveis e migrantes lateralmente.

Dobras penecontemporâneas em variadas escalas são comumente observadas, sendo consideradas estruturas diagnosticas desta unidade. Três processos podem ter contribuído para a sua formação: peso da carga sedimentar superimposta (este mecanismo causa a fluidização principalmente das fácies argilosas), movimentação de massas de gelo - a chegada de novas geleiras causa o arrasto do material sotoposto não litificado (neste caso, as dobras geradas são do tipo recumbentes e podem indicar a direção de fluxo das geleiras), crioturbação (deformação causada pela variação de volume de água conata a partir de seu congelamento/descongelamento).

FORMAÇÃO TABULEIRO Esta unidade possui uma morfologia de relevo bastante característica, com formas geomorfológicas de tabuleiros típicos, onde comumente se destacam canyons desenvolvidos ao longo de planos de fraturamento/falhamento.

É constituída por arenitos médios, vermelhos, rosados, brancos e maciços, dispostos em bancos horizontais. Os bancos arenosos são intercalados por delgados níveis argilosos que ocasionalmente alcançam alguns centímetros de espessura. $\mathrm{Na}$ base ocorrem camadas de argilitos pouco estratificados com grãos de quartzo foscos flutuantes. Na região de Urucuia, foram observados raros níveis de calcários microcristalinos e margas cinzas. Esta unidade é marcada por grande homogeneidade litológica.

Os arenitos e argilitos são dispostos em camadas planoparalelas. Além do acamamento plano-paralelo ocorrem, muito raramente, estratificações cruzadas.

A análise das seções delgadas dos arenitos mostra grãos de quartzo subarredondados a arredondados e esféricos, com diâmetros variando de 0,25 a $0,45 \mathrm{~mm}$, sendo raramente bimodais. $\mathrm{O}$ contato tangencial entre os grãos gera um arcabouço aberto com uma porosidade primária elevada (até 16\%), que é totalmente preenchida por um cimento de calcita com alto grau de cristalinidade.

Além do quartzo detrítico, ocorrem traços de minerais pesados (turmalina, granada, hornblenda, zircão e óxidos) e localmente fragmentos líticos da sucessão basal (siltitos e argilitos vermelhos). As características físicas e composicionais da maioria dos grãos dos arenitos da Formação Tabuleiro traduzem alta maturidade textural e mineralógica e excelente selecionamento. As feições texturais e composicionais permitem sua classificação como quartzo-arenitos calcíferos e arenitos feldspáticos calcíferos.

A Formação Tabuleiro apresenta uma distribuição mais ampla, recobrindo os membros da Formação Floresta, ocorrendo diretamente sobre o Grupo Bambuí. Seu contato com a unidade sotoposta é gradacional, sendo marcado pela intercalação de folhelhos do Membro Brejo do Arroz nos arenitos ou por intercalações de arenitos argilosos do Membro Lavado nos folhelhos.

Esta unidade representa a sedimentação periglacial eólica que se desenvolve sobre lagos rasos pós-glaciais.

A associação faciológica e a ausência de estruturas de tração nos arenitos, de certa forma, dificulta a caracterização ambiental desta unidade. Contudo, a análise petrográfíca por seções delgadas indica que as areias foram transportadas, retrabalhadas e depositadas por correntes eólicas.

A instalação de condições de sedimentação desérticas, em trato de sistemas glaciais, é bastante comum. Regiões periglaciais apresentam condições ideais para o transporte eólico, como ausência de vegetação, ventos constantes e disponibilidade de sedimentos erodidos (Schultz \& Frye 1968, Flint 1971 e Calkin \& Rutford 1974). Os sistemas desérticos periglaciais produzem os mesmos tipos de depósitos e estruturas dos desertos de baixas latitudes.

Proveniência A área fonte é interpretada como a região central do estado da Bahia a sudoeste da Chapada Diamantina, onde são representadas as seguintes unidades: Grupo Chapada Diamantina no segmento setentrional da Serra do Espinhaço, com quartzitos, filitos, vulcânicas ácidas e metaconglomerados líticos; sequências vulcano-sedimentares paleoproterozóicas com xistos, rochas básicas, itabiritos e milonitos; restritas faixas de terrenos Greenstone Belts com supracrustais diversas em fácies xisto-verde; terrenos de embasamento com gnaisses, granitos intrusivos, faixas miloníticas associadas e metadiamictitos do Grupo Macaúbas (Schobbenhaus et al, 1984).

Ainda é importante salientar que uma glaciação representa um processo erosional/ sedimentar, aluando em uma vasta região, amostrando áreas fontes diversas desde as proximidades dos centros glaciais e continuando por todo o trajeto das 
geleiras. Portanto, além das áreas fontes enumeradas anteriormente, consideradas como áreas fontes proximais aos centros glaciais, toda a região percorrida pelas geleiras é considerada área de proveniência. Estas regiões caracterizam as fontes distais em relação aos centros glaciais e são representadas pelo conjunto de rochas compostas por pelitos, calcários e arcóseos do Grupo Bambuí. Detalhes a respeito das áreas fonte são disponíveis em Campos \& Dardenne (1994).

GRUPO AREADO -EOCRETÁCEO Os sedimentos atribuídos ao Eocretáceo da Bacia Sanfranciscana, inicialmente estudados na região do Alto Paranaíba, foram tratados como grupo por Ladeira \& Brito (1968), Hasui \& Penalva (1970) e Kattah (1994) e como formação por Braun (1970), Cardoso (1971), Barcelos \& Suguio (1980) e Sgarbi (1989). A evolução dos estudos, principalmente através de trabalhos de superfície, levou ao reconhecimento da mapeabilidade das subunidades desta sucessão em escalas maiores que $1: 25.000$. Desta forma este trabalho propõe a volta da denominação de Grupo Areado para designação das rochas eocretáceas da Bacia Sanfranciscana.

Esta unidade está distribuída por toda a extensão da bacia, sendo de forma contínua na Sub-Bacia Abaeté e descontínua na Sub-Bacia Urucuia. No depocentro da Sub-Bacia Abaeté o Grupo Areado apresenta espessuras superiores a 200 metros e rápido adelgaçamento lateral, enquanto que para norte as espessuras desta unidade não ultrapassam algumas dezenas de metros.

O Grupo Areado é a unidade da Bacia Sanfranciscana com maior variação lateral de litofácies. As mudanças laterais são função da atuação simultânea de diversos ambientes deposicionais, entre os quais leques aluviais, fluviais entrelaçados, fluvio-deltáicos, lacustres, campo de dunas e interdunas.

\section{Caracterização Faciológica e Sedimentação do Grupo Areado O Grupo Areado é composto por três formações fortemente interdigitadas.}

FORMAÇÃO ABAETÉ A Formação Abaeté constitui a unidade basal do Grupo Areado. Apesar de não ser contínua, apresenta uma ampla distribuição horizontal, principalmente na porção centro-sul da bacia. A norte do paralelo $17^{\circ} 00$, ela é descontínua, sendo preservada ao longo de paleo-depressões. Esta formação é restrita à base da sucessão Areado, não tendo sido observada sua recorrência em porções estratigráficas superiores.

Os conglomerados da Formação Abaeté apresentam importantes diferenças petrográficas quando comparadas suas ocorrências no extremo sul e nas demais regiões da bacia. $\mathrm{Na}$ porção sul, região limitada à área afetada pelo soerguimento do Alto Paranaíba, ocorrem conglomerados polimíticos comumente sustentados pela matriz e com predomínio de clastos de metassiltitos do embasamento local. Já nas demais regiões da bacia, inclusive na área-tipo próximo a Abaeté/MG, os conglomerados são sustentados pelos clastos, com amplo predomínio de seixos de quartzitos e melhor grau de organização.

A espessura destes conglomerados varia de alguns centímetros a até 30 metros, ficando na maior parte dos casos, compreendida entre 0,5 e 2,0 metros. Quando a sua espessura atinge dezenas de metros, os conglomerados associam-se a inúmeras fácies arenosas, sempre preenchendo paleodepressões no embasamento.

A Formação Abaeté constitui o melhor guia estratigráfico da bacia, sendo fundamental para a separação da Formação Tabuleiro de outras unidades fanerozóicas arenosas.

$\mathrm{O}$ estudo petrográfico e faciológico é difícil em virtude da escassez dos afloramentos e de sua natureza inconsolidada, provocando o desmoronamento do material do arcabouço. $\mathrm{Na}$ região de Canabrava $\mathrm{MG}$, um espectro diversificado de litofácies de conglomerados, arenitos e folhelhos interrelacionados compõe o arcabouço interno da Formação Abaeté (Campos \& Dardenne, 1995).

A composição global dos seixos, matacões e calhaus praticamente fica constante nas diversas litofácies, sendo que quartzitos variados, quartzo de veio, quartzo hialino e formacões ferríferas bandadas (BIFs) correspondem a mais de $95 \%$ dos clastos. Outros fragmentos líticos como granitos, xistos e arcóseos são também encontrados, embora com frequência bem menor.

O conjunto dos minerais pesados presentes é composto por turmalina, hematita, magnetita, estaurolita, cianita, granada, ilmenita, grafita, topázio, além do diamante.

$\mathrm{O}$ alto grau de arredondamento, assim como a composição geral dos clastos, evidenciam a alta maturidade textural e mineralógica dos sedimentos da Formação Abaeté na porção centro-norte da bacia. Ao contrário, no extremo sul, observase relativa imaturidade composicional e textural com amplo predomínio de clastos alongados de metassiltitos.

A granulometria das fácies conglomeráticas é variada, sendo observados grânulos a calhaus e matacões com eixo maior em torno de $40 \mathrm{~cm}$. De maneira geral, o grau de selecionamento aumenta com a diminuição da proporção de matriz, sendo as fácies sustentadas por clastos melhor selecionadas que as fácies sustentadas por matriz.

A sedimentação da Formação Abaeté pode ser dividida em dois contextos distintos, os quais coincidem com as áreas de contrastes litológicos, onde o conjunto de litofácies permite separar uma região no extremo sul da bacia, com conglomerados imaturos, mais desorganizados e com considerável presença de matriz, e outra para as demais áreas de ocorrência na bacia, com conglomerados monomíticos, maturos e apresentando quantidade menor de matriz.

Porção sul da Sub-Bacia Abaeté Genericamente, pode-se dizer que a sedimentação da Formação Abaeté na porção sul da bacia ocorreu sob condições dominadas por leques aluviais.

Relevos elevados, com gradientes acentuados, são as principais condições necessárias para a instalação de leques aluviais (Collinson, 1987). O escalonamento de blocos, em função de falhas normais ligadas à formação da bacia, seria responsável pela geração de escarpas ao longo das quais se desenvolveriam os fluxos de detritos. Os debris flow foram os mecanismos mais importantes, sendo responsáveis pela deposição de conglomerados desorganizados e ricos em matriz; enquanto as correntes aquosas foram mais restritas, depositando arenitos em fácies canalizadas.

Outro fator, que corrobora com o ambiente proposto, é a alta imaturidade dos psefitos. Sgarbi (1989) detalha a composição dos clastos da Formação Abaeté no oeste do estado de Minas Gerais e mostra a predominância de fragmentos de natureza lítica do embasamento local $(-50 \%)$, o que implica em alta imaturidade composicional. A forma geral dos seixos também indica imaturidade textural, com formas comumente achatadas e alongadas. Os fragmentos angulosos são herdados a partir dos planos estruturais das litologias do embasamento (Grupo Bambuí), pois estes tendem a quebrar-se nas intersecções de planos de fraturas, acamamento e clivagem ardosiana.

As feições de acamamento inverso, localmente observadas, são geradas em condições específicas de viscosidade e velocidade do fluxo de detritos. Esta estrutura sedimentar foi gerada pelas correntes mais densas, que geralmente favorecem o cisalhamento interclastos e sua acumulação na porção superior de cada fluxo individual (Davies \& Walker 1974). As estruturas de imbricamento de seixos, por outro lado, são geradas comumente por fluxo aquoso, sendo encontradas em conglomerados sustentados por clastos, por isso sendo pouco 
comuns ou incipientes nas ocorrências de conglomerados da região sul da bacia.

Demais áreas da bacia $A$ sedimentação da Formação Abaeté, nas demais regiões da bacia, foi controlada por correntes aquosas em regime de fluxo superior, sendo dessa forma relacionada a um ambiente fluvial entrelaçado grosso capaz de depositar expressivas sucessões conglomeráticas. As interpretações ambientais referentes à região de Canabrava (Campos \& Dardenne 1995), podem ser estendidas às amplas áreas de ocorrência desta unidade em todo o segmento centronorte da bacia.

FORMAÇÃO QUIRICÓ É composta predominantemente por sedimentos pelíticos, com folhelhos e siltitos esverdeados, rosados, ocres, violáceos ou avermelhados, que ocorrem interestratificados entre si, apresentando rápidas variações de cores. Subordinadamente, ocorrem intercalações de arenitos finos, médios e grossos, os quais são mais frequentes na parte superior da sequềncia.

De maneira restrita, ocorrem fácies de calcários micríticos cinza esverdeados dispostos em bancos maciços associados aos pelitos (Sgarbi, 1989). Apenas confinados à região de Varjão-São José de Geribá, no Município de Presidente Olegário, ocorrem folhelhos pretos, ricos em material orgânico, refletindo um ambiente mais profundo. Esta fácies, além de apresentar uma distribuição restrita, mostra espessuras reduzidas, não superiores a 5 metros (Kattah, 1991)

De uma forma geral, as litologias pelíticas predominam na base da unidade, enquanto as intercalações arenosas se situam na porção mediana da seção, sendo mais comuns para o topo.

Além do proeminente acamamento plano-paralelo, diversas estruturas sedimentares são observadas: laminações e estratificações cruzadas, marcas onduladas assimétricas, climbing ripples, moldes de pseudomorfos de sais, marcas de sola, concreções carbonáticas e canais de corte e preenchimento.

A distribuição faciológica da Formação Quiricó é aceita de forma consensual nos mais diversos estudos (Barbosa et al. 1970, Seer et al 1989, Sgarbi 1989 e Kattah, 1991). Os trabalhos de campo indicam a presença de um lago de geometria alongada segundo a direção norte-sul, indo de Arapuá/MG ao sul até a foz do Ribeirão Andrequicé ao norte. O presente trabalho mostra que a Formação Quiricó se estende além do limite setentrional mencionado anteriormente.

As espessuras da Formação Quiricó variam de máximos em torno de 100 metros na região de Abaeté (Seer et al. 1989), reduzindo-se rapidamente para poucos metros nas bordas do sistema lacustre. Ao norte, suas ocorrências não ultrapassam algumas dezenas de metros.

Esta unidade se sobrepõe à Formação Abaeté ou recobre diretamente os metassedimentos do Grupo Bambuí. Lateralmente, observa-se a sua interdigitação com a Formação Três Barras que também a sobrepõe. Nos locais onde a interdigitação de fácies é mais intensa, é possível observar repetidas intercalações entre os depósitos arenosos e pelíticos, sendo comuns as estruturas de carga.

As espessuras expressivas da sucessão sedimentar, sem hiatos importantes (níveis erosivos extensos), indicam que os lagos não eram efêmeros, como propuseram alguns trabalhos anteriores. Caso ocorressem lagos intermitentes, estruturas de exposição aéreas e superfícies erosionais contínuas deveriam ser mais comuns.

Grande parte dos corpos arenosos que, por vezes, ocorrem intercalados aos folhelhos, foram depositados por correntes de turbidez de baixa densidade. Estes turbiditos rasos produzem marcas de sola, marcas onduladas assimétricas, camadas grano-decrescentes, figuras erosivas em bancos de arenitos e arenitos argilosos, comumente com formas lobadas.
Exposições subaéreas são principalmente observadas nas fácies marginais dos lagos, onde foram registrados pseudomorfos de cubos de sal e crostas carbonáticas, já que estes setores dos lagos são os mais susceptíveis a variações sazonais do nível da água.

A influência eólica é constante na sedimentação lacustre. Vários níveis centimétricos (de $3 \mathrm{a} 10 \mathrm{~cm}$ ) de arenitos, lateralmente contínuos e compostos por grânulos e grãos de areia élica, mostram que, simultaneamente à deposição dos pelitos, ocorria a migração e retrabalhamento de dunas nas adjacências dos lagos. As constantes interdigitações de fácies eólicas com os folhelhos também denunciam a simultaneidade entre a sedimentação lacustre e o retrabalhamento eólico subaéreo.

$\mathrm{Na}$ maior parte da bacia, os paleolagos eram representados por corpos d'água não estratificados, isto é, sem a presença de um hipolímio e um epilímio diferenciados. Provavelmente, apenas as porções centrais do Lago Quiricó (no sentido de Barbosa 1965) apresentavam um epilímio e um hipolímio que proporcionaram a estratificação do lago com lâmina d'água rasa oxidante e lâmina d'água mais profunda redutora (Selley 1982). Esta estratificação do paleolago explica a preservação da matéria orgânica nas regiões mais profundas do Lago, por condições crescentes de anoxia. Esta porção do lago também favorece a sedimentação carbonática que ocorre de forma subordinada apenas na Sub-bacia Abaeté.

FORMAÇÃO TRESS BARRAS Esta unidade do Grupo Areado apresenta a maior diversidade litológica, o maior volume de rochas e a mais ampla área de ocorrência. Também apresenta as maiores variações laterais de fácies, sendo constatada a atuação simultânea de sistemas fluviais, fluvio-deltáicos e desérticos.

As espessuras máximas alcançam 150 metros na Sub-Bacia Abaeté. Em direção ao norte, a unidade se adelgaça rapidamente, apresentando espessuras da ordem de 20 a 40 metros. Na Sub-Bacia Urucuia, esta formação ocorre apenas na forma de morros testemunhos isolados, com espessuras da ordem de 10 a 15 metros.

Na Formação Três Barras, predominam três fácies distintas de arenitos, descritas a seguir.

Fácies 1 É representada por arenitos médios, brancos, esverdeados ou rosados, dispostos em estratos cruzados de grande porte, com foresets tangenciais. Apresentam comumente granulometria bimodal, grãos esféricos com superficie fosca.

A análise de seções delgadas revela a predominância de grãos de quartzo monocristalino, com extinção desde normal a fortemente ondulante. Ocorre também importante contribuição de grãos líticos policristalinos (até 10\%), representados por quartzitos finos, metachert e principalmente por silexitos. O feldspato pode ocorrer em proporções variáveis, localmente alcançando $12 \%$, sendo representado por grãos de microclíneo pouco alterados. Os minerais pesados são de forma geral bastante esféricos e ocorrem Subordinadamente, tendo sido observados óxidos, turmalina e zircão.

As fácies cimentadas ocorrem distribuídas por toda a sucessão, sendo observados cimentos de carbonato e sílica. A cimentação principal é a de calcita que, em alguns casos, é tão intensa que dissolve a borda dos grãos de quartzo detríticos, dando um pseudo aspecto de contatos flutuantes. Em menores proporções, o cimento silicoso ocorre próximo aos contatos dos arenitos com os corpos alcalinos intrusivos. Sgarbi (1991) descreve detalhadamente esta fácies na porção sul da bacia.

Esta unidade é representada basicamente pela sedimentação eólica, tendo seus sedimentos e produtos diagenéticos sido detalhados por Sgarbi (1989 e 1991). 
Fácies 2 É constituída por arenitos médios a finos, brancos, amarelados, apresentando estratos decimétricos planoparalelos e estratificações cruzadas de médio e pequeno porte. Frequentemente ocorrem intercalações de delgados níveis argilosos. As fácies com maior porosidade primária apresentam cimento calcífero, comumente observado nas rochas menos intemperizadas.

Os arenitos rosados e vermelhos apresentam proporções de matriz argilosa variando de zero até $20 \%$. Na maioria dos casos, estes arenitos são classificados como wackes. A concentração de feldspatos é variável, ocorrendo desde quartzo arenitos a subarcósios (14 a 18\% de feldspatos). Nos arenitos vermelhos são comuns as manchas brancas interpretadas como produto de descoloração a partir de bioturbação ou manchas de alteração de feldspatos.

As principais estruturas encontradas são as-estratificações cruzadas, variando desde centimétricas até métricas, acanaladas, tabulares e truncadas. Feições características são o truncamento por erosão e as superfícies de reativação das estratificações cruzadas, principalmente as de pequeno porte. Os estratos cruzados tabulares geralmente apresentamforesets de pequeno ângulo. Outras estruturas sedimentares encontradas com menor frequência são as marcas onduladas, estruturas de fluidização e estruturas de carga (pseudo-nódulos e estruturas em chama).

$\mathrm{O}$ conjunto de tipos petrográficos, a rápida variação lateral de fácies, as estruturas sedimentares preservadas, os sistemas de paleocorrentes e a distribuição vertical e horizontal dos conjuntos individuais permitem enquadrar a sedimentação, dentro de um modelo fluvial entrelaçado dominado pela deposição de areias. Barras arenosas, canais ativos, planícies dominadas por lençóis arenosos e raros depósitos de planície de inundação representam os grandes domínios deposicionais relacionados à sedimentação fluvial desta fácies.

Fácies 3 É caracterizada por arenitos e wackes vermelhos, rosados, na forma de lentes, lobos (isolados ou amalgamados), canais, em bancos maciços, com estratificação plano-paralela ou em estratos cruzados tabulares e acanalados. São comuns os corpos arenosos de feições gerais sigmoidais. Esta fácies encontra-se bem desenvolvida na zona de transição entre as formações Três Barras e Quiricó.

A sedimentação fluvio-deltáica se processou nas interfaces dos canais fluviais e dos corpos aquosos dos lagos maiores. Este sítio deposicional também dá origem, em profundidade, às correntes de densidade responsáveis pela sedimentação dos turbiditos diluídos da Formação Quiricó.

Proveniência Na sucessão de sedimentos do Grupo Areado, a melhor determinação de paleocorrentes foi possível a partir dos conglomerados e arenitos da sua unidade basal (Formação Abaeté). Os vetores de paleocorrentes, obtidos por estratificações cruzadas e imbricamento de seixos, indicam direcões de fluxo de massa de $\mathrm{S} W$ para NE com uma dispersão de N30-35W até N45E e máximo para N10E. Estes dados foram obtidos na região de Canabrava. Medidas isoladas em outras ocorrências de conglomerados na bacia também fornecem valores que indicam transporte de SW para NE, mostrando grande persistência dos valores.

Considerando-se os vetores obtidos por Seer et al. (1989), Sgarbi (1989) e Kattah (1991) para os arenitos da Formação Três Barras na Sub-Bacia Abaeté, indicando paleocorrentes respectivamente orientadas para SSW; Norte/NE e SW, notase o importante controle da estruturação tectônica na determinação das áreas fontes. Este quadro de paleocorrentes mostra que existiam elevações do embasamento que controlavam as áreas fontes, possibilitando:

- transporte com áreas fontes situadas no sul da bacia, relacionadas ao início do soerguimento do Alto Paranaíba;
- transporte proximal a partir dos blocos internos elevados no interior da bacia, associados às falhas longitudinais ligadas à génese da bacia;

- transporte de oeste para leste a partir da borda da Faixa Brasília;

- transporte aproximadamente de leste para oeste a partir da Faixa Araçuaí.

A significativa presença de seixos de rochas metamórficas (quartzitos variados, gnaisses e BIFs) e a coincidência entre os conjuntos de minerais pesados da Formação Abaeté e do Grupo Santa Fé, indicam a importante contribuição dos sedimentos neopaleozóicos como fontes para a sedimentação cretácea. O amplo predomínio de seixos de quartzitos nos conglomerados da Formação Abaeté, confirma que ocorreu o retrabalhamento dos ruditos glaciais, já que os quartzitos apenas afloram a centenas de quilómetros das áreas de ocorrência da Formação Abaeté.

\section{GRUPO MATA DA CORDA -NEOCRETÁCEO}

caracterizado pela presença de rochas vulcânicas alcalinas efusivas e piroclásticas, plutônicas alcalinas e sedimentares epiclásticas. É dividido em duas unidades aqui denominadas de formações Patos e Capacete.

Na porcão sul da bacia (ao sul do paralelo 19³0'), o Grupo Mata da Corda se sobrepõe aos sedimentos do Grupo Areado, enquanto, a norte, o mesmo repousa sobre os arenitos do Grupo Urucuia.

Caracterização Litofaciológica do Grupo Mata da Corda FORMAÇÃO PATOS É composta por rochas alcalinas máficas a ultramáficas de natureza efusiva e piroclástica, com amplo predomínio dos tipos piroclásticos. O histórico sobre a evolução do conhecimento desta unidade foi apresentado por Leonardos et al. (1991)

Uma gama variada de tipos petrográficos são referidos na literatura, sendo as classificações baseadas em termos texturais e composicionais. Em termos texturais, são descritas lavas maciças afaníticas ou porfiríticas, basanitos vesiculares ou amigdalóidais, tufos lapflicos, brechas vulcânicas, cineritos (tufos a cinzas), etc., ou seja, desde derrames até rochas vulcânicas de origem explosiva com granulação variável de cinza até blocos e bombas (Moraes et al 1986). As rochas piroclásticas são geralmente cimentadas por fases minerais tardi-magmáticas como carbonatos, e fases diagenéticas como zeólitas e calcedônia.

Em termos composicionais, estas rochas são classificadas como kamafugitos por Moraes et al. (1987) e associações madupíticas/lamproíticas por Leonardos \& Ulbrich (1987). Sgarbi \& Valença (1991) citam composições kamafugíticas com afinidades ultrapotássicas (leucititos e kalsilititos). Discussões mais recentes, com base em estudos detalhados de petrografia, química mineral e distribuição dos elementos Terras Raras (e.g. Tallarico et al. 1993), indicam que o magmatismp do Grupo Mata da Corda apresenta características híbridas entre os clãs kimberlítico, lamproítico, kamafugítico e minetes, tendo levado Bizzi. (1993) a propor o termo inédito de Kimberlitos Brasileiros para sua classificação.

Os aparelhos vulcânicos (crateras e caldeiras) e os diques, plugs e necks, que alimentaram o vulcanismo, são também relacionados à Formação Patos.

Grande diversidade de nódulos mantélicos (xenólitos de granada lherzolito e cumulatos) são atribuídos a esta unidade, os quais a partir de estudos geotermo-barométricos, indicam profundidades variáveis para origem destes magmas alcalinos (e.g. Leonardos et al. 1993, Bizzi et al 1993 e Ramsay \& Tompkins 1993).

A distribuição desta unidade é restrita a porção sul da Sub-Bacia Abaeté, não sendo encontrada na área principal do presente estudo. 
Sobre a Formação Patos se desenvolve uma espessa canga laterítica brechóide de cor ocre/amarelada, que é totalmente distinta das coberturas de lateritos que se desenvolvem sobre as demais unidades em outras porções da bacia.

FORMAÇÃO CAPACETE É composta por rochas epiclásticas com granulometrias que variam desde argila até seixos e calhaus, sendo representadas por argilitos, arenitos líticos, wackes líticos, ortoconglomerados e paraconglomerados vulcânicos. Este conjunto apresenta cores que variam de tons verdes nas rochas mais frescas a tons rosados e avermelhados nas rochas intemperizadas.

A Formação Capacete representa o produto do retrabalhamento das rochas vulcânicas da Formação Patos, sendo constituída por rochas epiclásticas com fragmentos petrograficamente similares às rochas vulcânicas da Formação Patos.

Os sedimentos líticos desta unidade apresentam uma faciologia interna com importantes variações litológicas, que podem ser assim sumarizadas: ao sul, nas proximidades dos centros vulcânicos, esta unidade é composta por fácies psefíticas e psamíticas grossas como conglomerados e arenitos líticos grossos, geralmente intercalados a lavas e tufos (e.g. Morro do Sabão, na região de Carmo do Paranaíba); entre os paralelos $18^{\circ} 30^{\prime}$ e $18^{\circ} 00^{\prime}$, nas proximidades da área-tipo (Serra do Capacete) ocorrem predominantemente arenitos vulcânicos, geralmente cimentados por carbonatos e a norte do paralelo $18^{\circ} 00^{\prime}$, ao longo do Chapadão dos Gerais e da Serra do Formoso, ocorrem arenitos e diamictitos extremamente alterados, que representam os sedimentos mais distais do sistema deposicional Capacete.

A sedimentação da Formação Capacete pode ser considerada como um sistema de leques aluviais distais, transicionando para fácies fluviais entrelaçadas.

A contribuição eólica é evidente, sendo os grãos de quartzo esféricos e polidos interpretados como o produto da sedimentação pelo vento. A concorrência entre a sedimentação por fluxos de detritos e por processos eólicos fica clara quando se observa, localmente, o início de nucleação de dunas intercaladas aos arenitos líticos.

As condições climáticas gerais foram consideradas de semi-áridas a áridas durante a sedimentação da Formação Capacete, fato que pode ser determinado pelos processos sedimentares dominantes (fluxo de detritos e transporte eólico) e pela ausência de registro biológico (fósseis e icnofósseis).
Proveniência $\mathrm{O}$ modelo de distribuição dos sedimentos líticos da Formação Capacete pode ser determinado facilmente a partir do contexto paleogeográfico da porção sul da bacia, o qual é caracterizado pelo levantamento crustal da região do Alto Paranaíba e pelo desenvolvimento do magmatismo da Formação Patos. O relevo relacionado aos aparelhos vulcânicos, que ocorrem em uma região já elevada, corresponde à área fonte a partir da qual se desenvolve a sedimentação.

Outro critério, que pode ser utilizado para determinação da fonte, é a variação granulométrica que, de forma geral, diminui progressivamente a partir da região de ocorrência das rochas vulcânicas. Na porção sul, são comuns os conglomerados e arenitos grossos, enquanto os arenitos finos predominam para nordeste, na região do Chapadão dos Gerais.

Uma contribuição de sedimentos arenosos, provenientes da região nordeste, também deve ser considerada como parte integrante da proveniência desta unidade (figura 3 ).

GRUPO URUCUIA -NEOCRETÁCEO Representa a unidade de maior importância regional na área estudada, com o maior volume de rochas e a mais ampla distribuição em área na Sub-Bacia Urucuia. O Grupo Urucuia ocorre a partir do paralelo $17^{\circ} 00^{\prime}$, ocupando amplas regiões em direção ao norte até o sudeste do estado do Piauí, onde se sobrepõe aos sedimentos da Bacia do Parnaíba. Na porção sul da bacia, o posicionamento estratigráfico tem sido problemático, sendo considerado como equivalente da sedimentação distai da Formação Capacete (Ladeira \& Brito, 1968 e Barcelos \& Suguio, 1980) ou, em outros casos, confundida com a própria Formação Capacete alterada (Seer et al 1989).

Na realidade, o Grupo Urucuia é apenas parcialmente sincrônico ao vulcanismo do Grupo Mata da Corda. Os arenitos vulcânicos recobrem o Grupo Urucuia desde ao sul do paralelo $18^{\circ} 00^{\prime}$, sendo este contato perfeitamente observável ao longo da BR 356.

A contemporaneidade relativa entre o Grupo Urucuia e a Formação Capacete pode ser entendida a partir do aumento progressivo (de sul para norte) da proporção de areia quartzosa nas rochas epiclásticas (e.g. BR 356 na entrada para São Gonçalo do Abaeté em direção a Pirapora).

As ocorrências do Grupo Urucuia na Sub-Bacia Abaeté e no Alto do Paracatu são descontínuas, sendo em geral representadas por morros testemunhos, geomorfologicamente marcados por formas de relevo de mesetas típicas, que se destacam

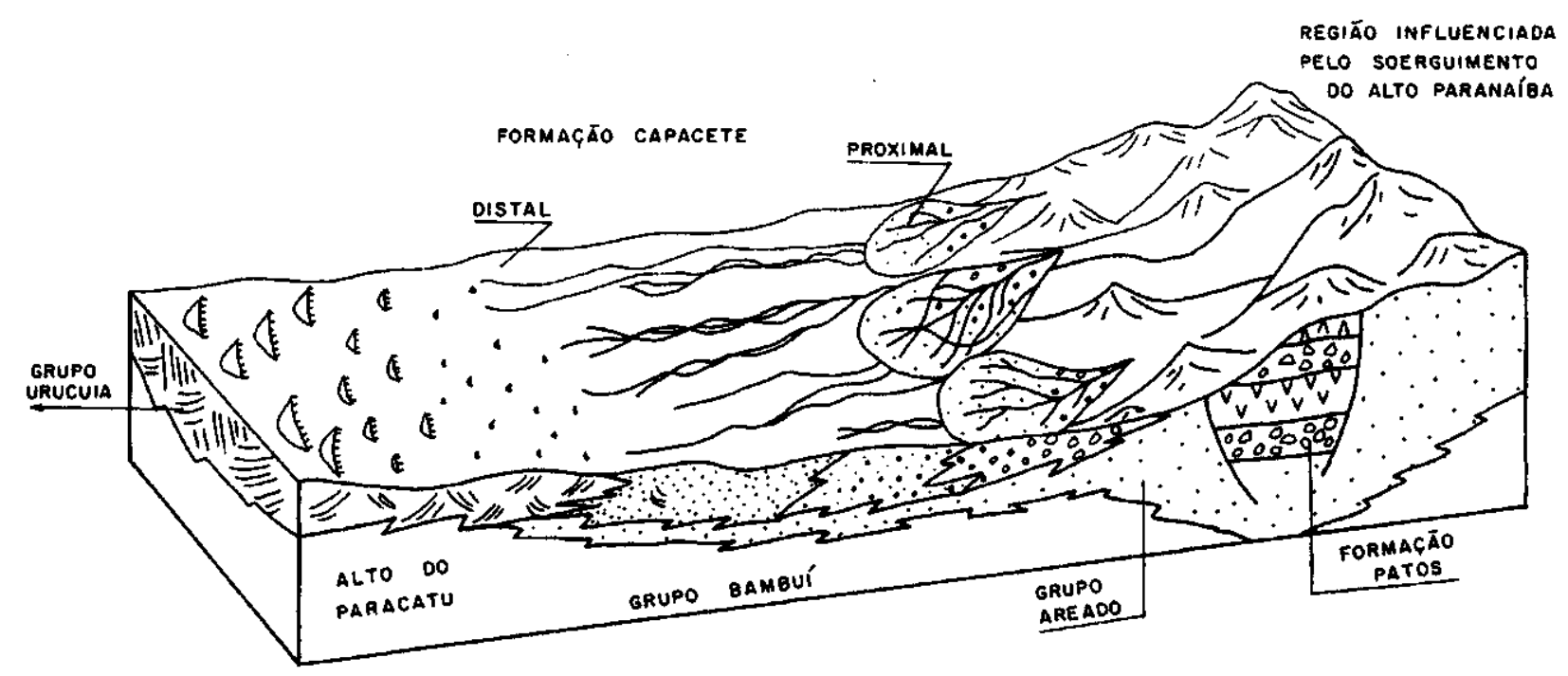

Figura 3 - Modelo paleogeográfico aplicado à sedimentação da Formação Capacete durante o Neocretáceo. Figure 3 - Palaeogeographic model applied to the Capacete Formation sedimentation during the Upper Cretaceous. 
na paisagem regional. Na sub-Bacia Urucuia, a norte do vale do rio homônimo, esta unidade ocorre de forma contínua até o sudeste do estado do Piauí.

As espessuras variam gradualmente de sul para norte, desde cerca de 25 metros (na região de São Gonçalo do Abaeté/MG), passando a 80 metros (região da Serra da Palmeira/MG) e alcançando cerca de 200 metros no meio norte da bacia (região de São Domingos/GO). No depocentro da bacia, Chang et al. (1992), baseando-se em dados sísmicos, estimam uma espessura da ordem de poucas centenas de metros. Esta unidade assenta-se, na maior parte da bacia, diretamente sobre o embasamento regional (Grupo Bambuí), podendo também recobrir localmente faixas granito gnáissicas, unidades do Grupo Santa Fé (e.g. região de Posse/GO), sobrepor-se à Formação Três Barras (e.g. região da Serra da Palmeira) ou à Formação Abaeté (e.g. Serra do Boqueirão na região Bonfinópolis de Minas).

Duas unidades podem ser caracterizadas, tendo sido classificadas com o status de formações. A unidade basal denominada de Formação Posse e comporta uma subdivisão interna nas Fácies 1 e 2. Sobrepondo a unidade anterior, ocorre a Formação Serra das Araras. A fácies 1 é amplamente dominante, contribuindo com cerca de $70 \%$ do conjunto.

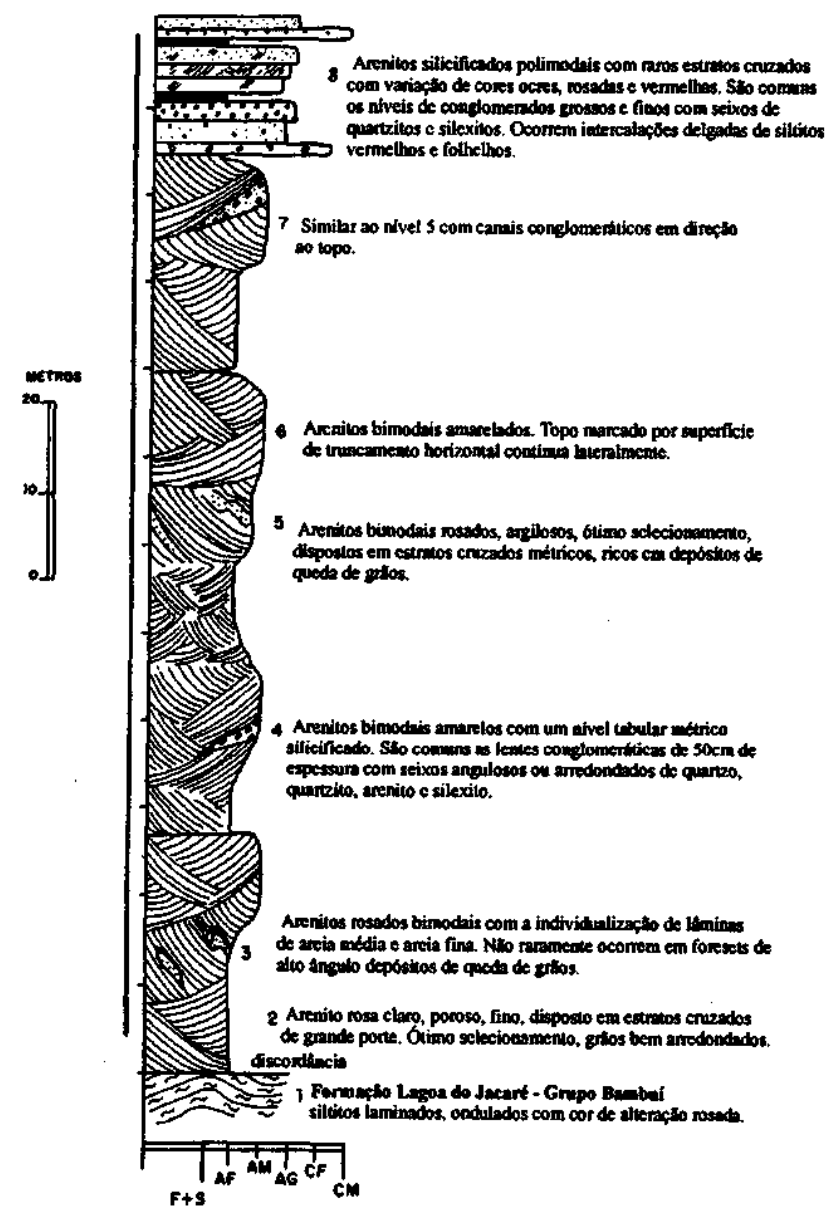

Figura 4 - Seção colunar integrada do Grupo Urucuia, incluindo a Formação Posse (caracterizada pelos litótipos de 2 a 7) e a Formação Serra das Araras (caracterizada pelos litótipos descritos no nível 8).

Figure 4 - Colunnar section of the Urucuia Group, showing the Posse Formation (lithotypes described by the units 2 to 7) and the Serra das Araras Formation (lithotypes described by the unit 8 ).
As áreas-tipo de exposição das unidades, são: para a Formação Posse, a região oeste do Morro da Água Quente nas proximidades da cidade de Posse/GO (nordeste de Goiás) e para a Formação Serra das Araras, o segmento leste da Serra das Araras próximo à vila homônima, (noroeste de Minas Gerais).

Caracterização Litofaciológica e Sedimentação do Grupo Urucuia FORMAÇÃO POSSE Fácies 1 $E^{\prime}$ constituída por arenitos muito finos, finos, médios, com boa maturidade textural e mineralógica, geralmente apresentando bom selecionamento.

Microscopicamente, são classificados como quartzo arenitos e mais raramente arenitos feldspáticos, sendo seu arcabouço constituído por 80 a $95 \%$ de quartzo monocristalino com extinção desde normal a fortemente ondulante. Em proporções reduzidas, ocorrem grãos de silexitos (até 10\%), feldspatos, principalmente microclíneo (9\%), quartzo policristalino, zircão, turmalina e epidoto.

Lâminas com gradação inversa e estruturas de adesão de grãos são localmente observadas.

Ocorrem lentes e níveis de conglomerados médios a finos, com seixos do próprio arenito, quartzo de veio e quartzitos, em qualquer posição estratigráfica. Uma cimentação silicosa frequentemente está associada a estes conglomerados.

As litologias, texturas, estruturas sedimentares e arranjo das fácies permitem relacionar a sedimentação da Fácies 1 desta sucessão a um sistema eólico de campos de dunas. Os principais argumentos, que suportam esta interpretação, são expostos a seguir:

- Disposição dos arenitos em estratos cruzados de grande porte, com planos de estratificação menor apresentando altos ângulos na porção superior (comumente $25-30^{\circ}$ ) e pequenos ângulos na porção basal.

- Pelos critérios de Glennie (1970), que utiliza a concentração estatística dos valores de paleocorrentes, as dunas do sistema eólico são classificadas como dunas barcanas típicas e localmente barcanóides. Dunas do tipo seif foram observadas apenas isoladamente.

- Ótimo selecionamento dos depósitos arenosos e constante predominância da fração areia fina e média. Estas características são atribuídas aos processos de transporte pelo vento.

- A bimodalidade é outro fator petrográfico típico de ambientes eólicos.

- Outra importante propriedade dos arenitos desta fácies é a ausência de matriz argilosa detrítica (a ausência de matriz argilosa é uma característica típica do retrabalhamento eólico). A pequena proporção argilosa encontrada é atribuída a processos de infiltração mecânica e alteração de feldspatos detríticos.

- Presença de estruturas de deslizamento de grãos na porção frontal das dunas. As feições de fluxo e queda de grãos são exclusivas dos depósitos eólicos de dunas secas.

- A evolução diagenética tipicamente continental caracterizando uma sucessão de red beds. Os principais produtos diagenéticos observados são: película de óxidos na borda dos grãos e cimentação por sílica, que ocorre em posições estratigráficas isoladas (grande parte das extensas superfícies de truncamento de primeira ordem coincidem com os bancos silicificados).

- A constante presença de crostas silicosas e seu retrabalhamento eólico, marcado pelos grãos detríticos de silexitos nos arenitos, é uma feição comum dos depósitos eólicos. 
Fácies 2 É constituída por arenitos brancos, ocres, finos, argilosos ou não, bem selecionados e, comparativamente aos arenitos da fácies 1 , menos maturos.

São classificados como arenitos feldspáticos e quartzo arenitos, onde o quartzo monocristalino é o fragmento mais comum. Contém ainda feldspatos (geralmente alterados), epidoto, zircão, turmalina e opacos como minerais acessórios subordinados. Grãos de quartzo esféricos com aspecto fosco ocorrem isolados no arcabouço detrítico, sendo importantes por evidenciar significativo contraste no conjunto geral do arenito, sendo uma feição comum nas seções delgadas descritas.

Ao contrário dos arenitos da Fácies 1, o material argiloso presente foi interpretado como matriz verdadeira por ocorrer em maior frequência, apresentar grau de cristalinidade reduzido e grande frequência de esmectita. As feições microscópicas também indicam se tratar de matriz detrítica, pois ocorre comumente em níveis mal selecionados, não raramente associados a siltitos argilosos.

Estratificações cruzadas tabulares e tangenciais de pequeno porte (até $30 \mathrm{~cm}$ ) são comuns e os estratos plano-paralelos mais raros.

A cimentação por sílica ocorre restrita a bancos horizontais.

Esta fácies é interpretada como produto de deposição por um sistema fluvial entrelaçado psamítico.

Foram identificadas as fácies Sp, Sn, e Sr de Miall (1977 e 1978). As fácies Sp são caracterizadas por arenitos com estratos cruzados tabulares decimétricos, que constituem conjuntos de até 3 metros de espessura. Sua deposição é controlada pela migração de formas de leito onduladas, com superfícies de reativação localmente comuns. As fácies $\mathrm{Sr}$, com pequenas estratificações cruzadas isoladas, são depositadas pela migração de dunas sob lâmina d'água reduzida. As fácies $\mathrm{Sh}$, caracterizadas por arenitos em camadas plano-paralelas internamente maciças, apresentam-se frequentemente silicificadas. Raramente se observa lineação de partição caracterizando condições de regime de fluxo superior em estágios de descarga elevada.

A influência da sedimentação eólica é interpretada a partir da observação em seções delgadas de grãos isolados característicos do retrabalhamento eólico.

O Rio Nilo, nas regiões onde secciona campos de dunas no norte da África, pode ser visto como um sistema análogo atual da sedimentação da Fácies 2.

FORMAÇÃO SERRA DAS ARARAS É constituída por arenitos, argilitos, e conglomerados com coloração avermelhada, intercalados em bancos plano-paralelos com espessuras variando de $50 \mathrm{~cm}$ a 2 metros.

Os arenitos são polimodais, silicificados, vermelhos e com níveis amarelados. $\mathrm{O}$ estudo microscópico mostra maturidade composicional e imaturidade textural. A cimentação por sílica e óxidos de ferro é localmente tão intensa que a rocha perde sua estruturação interna, assemelhando-se a um silexito. $O$ quartzo é dominante, sendo a turmalina e o zircão subordinados. Estratificações cruzadas acanaladas de pequeno porte são observadas, sendo os estratos plano-paralelos mais comuns.

Os conglomerados finos e grossos formam níveis de até $50 \mathrm{~cm}$, situados geralmente na base de níveis de arenitos. São sempre vermelhos com seixos de quartzo, quartzitos, arenitos da própria sequência, e feldspatos caolinizados. A matriz arenosa não ultrapassa $10 \mathrm{a} 15 \%$ e apresenta as mesmas feições texturais dos arenitos intercalados. É comum a presença de cimento de sílica e óxido de ferro. A cimentação quando desenvolvida intensamente, provoca a corrosão das bordas dos grãos detríticos, sendo responsável pela presença de contatos pseudo-flutuantes.
Na porção superior desta unidade, ocorrem horizontes pelíticos de até $50 \mathrm{~cm}$ (excepcionalmente 1 metro na Serra das Araras/MG), vermelhos e geralmente muito oxidados.

Esta sucessão, com espessura mínima de 25 metros se sobrepõe às fácies 1 e 2 . As melhores exposições são encontradas na porção superior da Serra Geral de Goiás e morros testemunhos da porção sul da bacia.

Representa a sedimentação fluvial desenvolvida em amplas planícies, apresentando grande variação do regime e carga dos fluxos. A deposição foi dominada por processos de fluxos aquosos com tração e subordinadamente por suspensão.

A contribuição eólica é indicada pela constante presença de grãos transportados pelo vento (esféricos e polidos), isolados no arcabouço dos arenitos ou flutuantes nos pelitos (siltitos e argilitos). O retrabalhamento das fácies 1 e 2 é evidenciado pela presença de seixos de arenitos destas fácies presentes nos bancos conglomeráticos.

Proveniência Dickinson et al. (1983) e Dickinson (1985) propuseram o uso de diagramas discriminantes para a determinação da proveniência de arenitos. Esta técnica considera a concentração modal dos componentes detríticos, calculados a partir da contagem de pontos de seções delgadas. Estes diagramas triangulares foram aplicados para plotar os resultados obtidos para o Grupo Urucuia. A maior parte das amostras do Grupo Urucuia plotam no campo dos "orógenos reciclados" e poucas amostras nos campos "cratônicos" e "transicional continental". A proveniência mais importante foi relacionada a fontes "quartzosas recicladas" com menores contribuições "cratônicas" e "transicional continental". Como a composição detrítica original não foi alterada pelos processos diagenéticos, essa metodologia é especialmente aplicável ao Grupo Urucuia. Os processos diagenéticos não produziram intensas mudanças na composição original dos arenitos, como dissolução de feldspatos e fragmentos líticos ou substituição de grãos detríticos por cimentes.

Simultaneamente com a metodologia de Dickinson et al. (1983), foi realizado um estudo estatístico dos dados de paleocorrentes (a partir de estratificações cruzadas) nas regiões de São Domingos e Posse. Os resultados indicam máximos para S60-70W com maior dispersão no quadrante SW.

A análise integrada dos diagramas ternários e dos dados de paleocorrentes indica uma proveniência a partir da porção nordeste do Cráton do São Francisco (principalmente Serra do Espinhaço Setentrional), concordando assim com uma fonte predominantemente quartzosa reciclada com origem a leste/nordeste da bacia.

FORMAĈ̃O CHAPADÁO -CENOZÓICO A designação de Formação Chapadão pretende resgatar a denominação de arenito chapadão de Ladeira \& Brito (1968) como referência às coberturas cenozóicas dominantemente arenosas da Bacia Sanfranciscana. Essa unidade inclui todas as coberturas quaternárias similares às da Formação Cachoeirinha nas bacias do Paraná e Parecis.

Como se trata de uma unidade com características petrográficas distintas das tradicionais unidades geológicas, não serão propostas áreas-tipo ou holoestratótipo para esta unidade, sendo suas exposições facilmente observadas em voçorocas, cortes de estradas e vales de drenagens distribuídos por toda a extensão da bacia.

Essas coberturas inconsolidadas podem ser classificadas como coberturas aluvionares, coluvionares e eluvionares.

Coberturas aluvionares São associadas à planície de inundação das maiores drenagens. São caracterizadas por depósitos resultantes do retrabalhamento fluvial recente de materiais detríticos diversos. Apresentam espessuras 
variáveis, alcançando 10 metros. Este conjunto inclui os materiais de retrabalhamento dos canais das drenagens atuais (aluviões sensu strictu) e os terraços aluviais (paleo-canais fluviais).

De maneira geral são representadas por sedimentos inconsolidados com cascalhes, areias e argilas/silte. A sucessão é composta por lentes, pacotes lenticulares maciços internamente ou preservando estratificações cruzadas e canais erosivos. Os cascalhes ocupam as porções basais e são constituídos por seixos de quartzitos e de arcósios e metassiltitos do embasamento local. De forma geral, os materiais psamitícos e psefitícos apresentam abundante matriz argilosa.

Coberturas coluvionares São resultantes de pequenos retrabalhamentos das unidades fanerozóicas e da regressão de formas de relevo tabular elevado (mesetas, tabuleiros, Serra Geral de Goiás). São constituídas por areias vermelhas ou esbranquiçadas onde a fração argilosa normalmente alcança $30 \%$, sendo constituída quase exclusivamente por caolinitas expansíveis.

Coberturas eluvionares Correspondem às areias inconsolidadas, que se desenvolvem a partir dos arenitos pertencentes às diversas unidades fanerozóicas. São representadas por depósitos in situ ou pouco retrabalhados, que atingem espessuras da ordem de 20 a 30 metros. Se distribuem nas extensas chapadas de cotas superiores a 800 metros, sendo mais comuns sobre os arenitos do Grupo Urucuia. A fração argilosa varia de 14 a $23 \%$, sendo constituída por caolinita de alto grau de cristalinidade.

CONCLUSÕES A subdivisão estratigráfica mais funcional para as unidades fanerozóicas da Bacia Sanfranciscana é definida por cinco grandes unidades separadas por importantes superfícies de discordâncias regionais. As sucessões foram organizadas de acordo com a seguinte nomenclatura e cronoestratigrafia: Grupo Santa Fé, Permo-Carbonífero, subdividido nas formacões Floresta e Tabuleiro', Grupo Areado, Aptiano-Albiano, composto pelas formações Abaeté, Ouiricó e Três Barras; Grupo Mata da Corda, Maastrichtiano, integrado pelas formações Capacete e Patos; Grupo Urucuia Eocretáceo, constituído pelas formações Posse e Serra das Araras, e Formação Chapadão, Quaternário, representando as coberturas recentes.
O embasamento da Bacia Sanfranciscana é representado principalmente pelo Grupo Bambuí, sendo observadas áreas mais restritas onde a bacia está assentada sobre unidades paleozóicas da Bacia do Parnaíba a norte, sobre restritas faixas de rochas granito-gnáissicas no meio-norte e metassedimentos do Mesoproterozóico no extremo sul da bacia.

A Formação Abaeté apresenta diferenças significativas quando comparadas as suas exposições na região do Alto Paranaíba com as nas demais regiões da bacia. No Alto Paranaíba é composta por conglomerados polimíticos sustentados pela matriz, enquanto a norte é essencialmente caracterizada por ortoconglomerados com seixos de quartzitos.

A deposição do Grupo Urucuia é parcialmente sincrônica ao Grupo Mata da Corda, sendo sua interdigitação bem exposta na região do Chapadão dos Gerais.

O Grupo Santa Fé representa um trato de sistema glacial continental de baixo relevo, com sedimentos atribuídos as zonas supra- e pró-glaciais e subambientes de base de geleiras, fluvio-glacial, glacio-lacustre e periglacial eólico-lacustre associados. Esta unidade assinala os registros da glaciação gonduânica na Bacia Sanfranciscana.

O Grupo Areado é marcado por intensa variação lateral de sistemas deposicionais. A Formação Abaeté representa leques aluviais no extremo sul da bacia e sistemas fluviais entrelaçados grossos nas demais ocorrências. A Formação Quiricó é essencialmente lacustre com depósitos de turbiditos de baixa densidade associados. A Formação Três Barras representa ambientes eólicos (dunas e interdunas), fluviais entrelaçados arenosos e fluvio-deltáico.

A Formação Capacete foi depositada sob condições de leques aluviais. As fácies proximais se encontram na região sul da Sub-Bacia Abaeté e as fácies distais se distribuem até o Alto do Paracatu.

O Grupo Urucuia é representado por três condições deposicionais distintas. A Formação Posse é caracterizada por campos de dunas (Fácies 1) e fluvial entrelaçado psamítico (Fácies 2). A Formação Serra das Araras foi depositada em ambiente fluvial com deposição por lençóis de areias e cascalhes.

A sedimentação da Cobertura Fanerozóica do Cráton do São Francisco ocorreu essencialmente sob condições continentais. A proposta de ambiente marinho profundo, a partir da determinação de radiolários (topo da Formação Quiricó) num contexto essencialmente desértico, merece estudos mais detalhados.

\section{REFERENCIAS}

Aitken, J.D. 1991. Two Late Proterozoic glaciations, Mackenzie Mountains, northwestern Canada. Geology, 19:445-448.

Ashley, G.M.; Shaw, J. \& Smith, N.D. 1985 (EdS.). Glacial sedimentary environments. SEPM Short Course 16. $246 \mathrm{p}$.

Barbosa, O. 1965. Formação Areado. In: Congresso Brasileiro de Geologia, 19, SBG, Rio de Janeiro, 1965, Anais...Rio de Janeiro.

Barbosa, O; Braun, O.P.G.; Dyer, R.C. \& Cunha, C.A.B.R. 1970. Geologia da região do Triângulo Mineiro. DNPM/DFPM, Boi. 136, Rio de Janeiro. 140p.

Barcelos, J.H. \& Suguio, K. 1980. Distribuição regional e estratigráfica das formações cretácicas do oeste mineiro. In: Congresso Brasileiro de Geologia, 31, Camboriú, 1980. Anais....Camboriú, SBG. Vol. 2 p. 683-690.

Bizzi, L.A. 1993. Mesozoic alkaline volcanism and mantle evolution of the southwestern São Francisco Cráton, Brazil. University of Cape Town. (PhD Thesis). 240p.

Bizzi, L.A.; De Wit, M.J.; Smith, C.B. \& Armstrong, R.A. 1993 Características isotópicas e origem dos kimberlitos e vulcânicas alcalinas relacionadas em Minas Gerais. In: Simpósio Brasileiro de Geologia do Diamante, 1. Anais...Cuiabá. UFMT Publ. Esp. 2/93. p. $141-151$.

Bouma, A.H. 1962. Sedimentology of some flysh deposits: a graphic approach to fácies interpretation. Amsterdan, Elsevier, 168p.
Braun, O.P.G. 1970. A Formação Areado e a Formação Serra Negra. Revista da Escola de Minas. 8:100-106

Calkin, P.E. \& Rutford, R.H. 1974. The sand dunes of Victoria Valley, Antarctica. Geographical Review, 64:189-216.

Campos, J.E.G. \& Dardenne, M.A. 1994. A carta estratigráfica da Bacia Sanfranciscana. Congresso Brasileiro de Geologia, 38, Camboriú, Boletim de Resumos, p. 54-56.

Campos, J.E.G. \& Dardenne, M.A. 1995. O sistema fluvial entrelaçado dos conglomerados e arenitos do Membro Abaeté na região de Canabrava MG. Geociencias, São Paulo, 14:73-96.

Chang ,H.K.; Bender, A.A \& Kowsmann, R.O. 1992. O papel das tensões intraplaca na evolução de bacias sedimentares: exemplo da Formação Urucuia. In: Congresso Brasileiro de Geologia, 37. São Paulo, 1992. Anais...São Paulo, SBG. Vol. 2,. 568 e 569.

Collinson, J.D. 1987. Deserts. In: Reading, H.G.(Ed.). Sedimentary Environments and Fácies. Blackwell Scientific Publications. p.95-112.

Dardenne, M.A.; Gonzaga, G.M. \& Campos, J.E.G. 1991. The diamond-bearing Cretaceous conglomerates of the Canabrava área, Minas Gerais, Brazil. Sth International Kimberlite Conference. Field Cuide Book. Araxá. CPRM. p. 83-88.

Davies, I.C. \& Walker, R.G. 1974. Transport and deposition of resedimentary conglomerates: The Cap Enrage Formation, Cambro-Ordovician, Gaspé, Quebec. Jour. Sed. Petrology, 44:1200-1216. 
Dickinson, W.R 1985. Interpreting provenance relations from detrital modes of sandstones. In: Provenance of Arenites. Zuffa, G.G. ed. Nato Asi Series D. Reidel Publishing Company. p. 333-361.

Dickinson, W.R.; Beard, L.S.; Brakenridge, G.R.; Erjavec, J.L.; Ferguson, R.C.; Inman, K.F.; Knepp, R.A.; Lindberg, F.A. \& Ryberg, P.T. 1983. Provenance of North American Phanerozoic sandstones in relation to tectonic setting. Geol. Soe. America Bull., 94:222-235.

Dott, R.H. 1964. Wacke, graywacke and matrix -What approach to immature sandstone classification? Jour. Sed. Petrology, 34:632-635.

Elliot, R.E. 1965. A classification of subaqueous sedimentary structures based on rheological and kinematical parameters. Sedimentology, (5): 193-209.

Eyles, N.; Eyles, C.H. \& Miall, A.D. 1983. Lithofacies types and vertical profiles models; an alternative approach to the description and environmental interpretation of glacial diamict and diamictic sequences. Sedimentology, 30:393-410.

Flint, R.F. 1971. Glacial and Quaternary geology. John Willey \& Sons. New York. 892p.

Folk, R.L. 1956. The role of texture and composition in sandstone classification. Jour. Sedimen. Petrology, 26:166-171.

Glennie, K. W. 1970. Desert sedimentary environments. Amsterdan, Elsevier. $222 \mathrm{p}$

Hasui, Y. \& Haralyi, N.L.E. 1991. Aspectos lito-estruturais e geofísicos do soerguimento do Alto Paranaíba. Geociências, São Paulo, 10:57-77.

Hasuy, Y. \& Penalva, F. 1970. O problema do diamante do Alto Paranaíba, Estado de Minas Gerais. SBG Núcleo São Paulo. Boi. 19 (1):71-78.

Kattah, S.S. 1991. Análise faciológica e estratigráfica do Jurássico/Cetáceo Inferior da Porção Meridional da Bacia do São Francisco, Oeste do Estado de Minas Gerais. Dissertação de Mestrado. UFOP. Ouro Preto. 213pp. (inédita).

Kattah, S.S. 1994. Pegadas de dinossauros no Grupo Areado, porção meridional da Bacia Sanfranciscana, Oeste de Minas GeraisAnais da Academia brasileira de Ciências, 66:181-187.

Ladeira, E. A. \& Brito, O.E.A. 1968. Contribuição à geologia do Planalto da Mata da Corda. In: Congresso Brasileiro de Geologia, 22. Belo Horizonte, 1968. Anais....Belo Horizonte, SBG. Vol. 1 p. 181-199.

Ladeira, E.A.; Braun, O.P.G.; Cardoso, R.N. \& Hasuy, Y. 1971. O Cretáceo em Minas Gerais. In: Congresso Brasileiro de Geologia, 25. São Paulo, 1971. Anais....São paulo, SBG. Vol. 1 p. 15-31.

Leonardos, O.H. \& Ulbrich, M.N.C. 1987. Lamproítos de Presidente Olegário, Minas Gerais. In: Reunião Anual SBPC, 36. Brasília.

Leonardos, O.H.; Gibson, S.A.; Thompson, R.N.; Moreira Filho, R.D. \& Magalhães, A.C. 1993. Geoquímica da intrusão ultramáfica ultrapotássica da Bocaina, Minas Gerais/Goiás: mais um exemplo de rocha sem classificação na província magmática do Alto Paranaíba. In: Simpósio Brasileiro da Geologia do Diamante, 1. Anais... Cuiabá. UFMT Publ. Esp. 2/93. p. 129-140.

Leonardos, O.H.; Ulbrich, M.N.C. \& Gaspar, J.C. 1991. The Mata da Corda volcanic rocks. Sth International Kimberlite Conference. Field Cuide Book. Araxá. CPRM. p. 65-73.

Lowe, D.R. 1975. Water escape structures in coarse grained sediments. Sedimentology, (22): 1 57-204.

Martins, E.S.; Lopes-Assad, M.L. \& Campos, J.E.G. 1993. Comportamento de solos desenvolvidos de arenito Urucuia. In: Congresso Brasileiro Ciências do Solo, 24. Goiânia. Resumos Vol. II p 351-352.

Miall, A.D. 1977. A review of the braided-river depositional environment. Earth Sci. Review, 13:1-62

Miall, A.D. 1978. Lithofacies types and vertical profiles in braided river deposits: a summary. Memoir of Canadian Society Petroleum Geologists, 5:597-605.
Moraes, L.C.; Seer, H.J. \& Kattah, S.S. 1987. Aspectos petroquímicos das rochas vulcânicas alcalinas cretáceas da porção meridional da Bacia Sanfranciscana, MG. In: Congresso Brasileiro de Geoquímica, 1 Porto Alegre, 1987. Anais.... Porto Alegre, SBG, Vol. 1. p.315-318.

Moraes. L.C.; Seer, H.J.; Fogaça, A.C.C.; Sgarbi, P.B.A. \& Sgarbi, G.N.C. 1986. 'Geologia das unidades Cretácicas da área compreendida entre Lagoa Formosa e Carmo do Paranaíba - MG. In: Congresso Brasileiro de Geologia, 34. Goiânia, 1986. Anais....Goiânia, SBG. Vol. 1 p. 337-344.

Mutti, E. 1992. Turbidite sandstones. S. Donato Milanese, Agip S.A.p. 275p.

Petri, S; Coimbra, A.M.; Amaral, G. \& Ponçano, W.L. 1986a. Guia de nomenclatura estratigráfica. Revista Brasileira de Geociências, 16:376-415.

Petri, S; Coimbra, A.M.; Amaral, G; Ojeda Y Ojeda, H; Fúlfaro, V.J. \& Ponçano, W.L. 1986b. Código brasileiro de nomenclatura estratigráfica. Revista Brasileira de Geociências, 16:372-376.

Ramsay, R.R. \& Tompkins, L.A. 1993. The geology, heavy mineral concentrate mineralogy, and diamond prospectivity of the Boa Esperanca and Cana Verde pipes, Córrego D'Anta, Minas Gerais, Brazil. In: Meyer, H.O.A. \& Leonardos, O.H. (Eds.) Proceedings of Sth International Kimberlite Conference, Araxá, CPRM Spec. Publ. Vol. 1B.

Resende, M.; Carmo, D.N.; Rezende, S.B.; Barros, N.F. \& Couto, E.G 1984 Levantamento dos recursos de solo para uso: Sudoeste de estado da Bahia - Interflúvio Arrojado/Veredãozinho. Universidade Federal de Viçosa/ FLORYL - Florestadora Ypê SA. 129p.

Sad, J.H.G.; Cardoso, R.N. \& Costa, M.T. 1971. Formações Cretáceas em Minas Gerais: uma revisão. Revista Brasileira de Geociências, 1:2-13

Schobbenhaus, C.; Campos, D.A.; Derze, G.R. \& Asmus, H.E. 1984 Geologia do Brasil. Texto explicativo do mapa geológico do Brasil e da área oceânica adjacente incluindo depósitos minerais (escala 1:250.000). ME/DNPMBrasília. 501p.

Schultz, C.B. \& Frye, J.C. 1968. Loess and related eolian deposits of the world. Univ. Nebraska Press. 345p.

Seer, H.J.; Moraes, L.C. \& Fogaça, A.C.C. 1989. Roteiro geológico para a região de Lagoa Formosa-Chumbo-Carmo do Paranaíba, MG. SBG. Núcleo Minas Gerais, Belo Horizonte, Boi. 9. 58pp.

Sslley, R.C. 1982. An introduction to Sedimentology. London Acad. Press. Inc. 2 edition. $417 \mathrm{p}$.

Sgarbi, G.N.C. 1989. Geologia da Formação Areado. Cretáceo Inferior a Médio da Bacia Sanfranciscana, Oeste do Estado de Minas Gerais. Rio de Janeiro. (UFRJ). 324pp. (dissertação de mestrado - inédita).

Sgarbi, G.N.C. 1991. Arenitos eólicos da Formação Areado (Bacia Cretácea do São Francisco): caracterização, diagênese e aspectos químicos. Revista Brasileira de Geociências, 21:342-354

Sgarbi, G.N.C., Horn, H.A. \& Sad, J.H.G. 1993. Aspectos químicos e isotópicos dos sedimentos lacustres da Formação Areado, bacia cretácica do São Francisco, MG. Anais Academia brasileira de Ciências, 65:265-270.

Sgarbi, P.B.A. \& Valença, J.G. 1991. Petrography and general chemical features of potassic mafic to ultramafic alkaline volcanic rocks of Mata da Corda Formation, Minas Gerais State, Brazil. Sth International Kimberlite Conference. Extended abstracts. Brazil. p. 359-360.

Tallarico, F.H.B.; Leonardos, O.H.; Gibson, S.A.; Meyer, H.O.A.; Mitchell, J.C. 1993. Química mineral da intrusão da Mata do Lenço (IML), Abadia dos Dourados, MG. In: Simpósio Geologia do diamante, 1. Anais... Cuiabá. UFMT, Public. Especial 2/93, p. 114-128.

MANUSCRITO A-918

Recebido em 04 de junho de 1997 Revisão dos autores em 28 de outubro de 1997 Revisã 0 aceita em 30 de outubro de 1997 